\title{
A Phylogenetic Analysis of the Family Dermatophilaceae
}

\author{
By ERKO STACKEBRANDT, ${ }^{1 *}$ REINER M. KROPPENSTEDT ${ }^{2}$ AND \\ VALERIE J. FOWLER ${ }^{1}$ \\ ${ }^{1}$ Lehrstuhl für Mikrobiologie, Technische Universität München, Arcisstrasse 21, D-8000 \\ München 2, Federal Republic of Germany \\ ${ }^{2}$ Deutsche Sammlung von Mikroorganismen, Gesellschaft für Biotechnologische Forschung \\ m.b.H. Braunschweig, Schnittspahnstrasse 9, D-6100 Darmstadt, Federal Republic of Germany
}

(Received 22 October 1982; revised 24 December 1982)

\begin{abstract}
The comparative analysis of the $16 \mathrm{~S}$ ribosomal ribonucleic acid (rRNA) of Geodermatophilus obscurus DSM 43060 and Dermatophilus congolensis DSM 43037 revealed that these members of the family Dermatophilaceae were only remotely related. While G. obscurus represented an individual and separate line of descent within the phylogenetically defined order Actinomycetales, D. congolensis was closely related to representatives of Arthrobacter, Micrococcus, Cellulomonas, Brevibacterium, Promicromonospora and Microbacterium.
\end{abstract}

\section{INTRODUCTION}

The family Dermatophilaceae is one of the eight families constituting the order Actinomycetales (Gottlieb, 1974). The Dermatophilaceae harbours two genera, Dermatophilus and Geodermatophilus, each with a single species, D. congolensis and G.obscurus, respectively. Geodermatophilus was included in the Dermatophilaceae by Luedeman (1968), mainly on the basis of a single morphological character, namely the ability to divide in transverse and longitudinal planes to form masses of cuboid cells. Quoting Roberts (1981), 'This may be an excessive significance to attach to a simple structural characteristic ...

The two species are identical only in peptidoglycan type (Lechevalier et al., 1971), while they show significant differences in DNA G + C content (Samsonoff et al., 1977), in whole cell sugars and phospholipid composition (Lechevalier \& Lechevalier, 1981) and in their morphological development (Roberts, 1981). As pointed out by Samsonoff et al. (1977) the significant difference in the DNA G + C content of about $15 \mathrm{~mol} \%$ makes it unlikely that $G$. obscurus and D. congolensis are representatives of two closely related genera. Doubt has also been cast on the specific relatedness of $G$. obscurus and $D$. congolensis by the results of a numerical taxonomic study (Goodfellow \& Pirouz, 1982). The question is whether the two genera are phylogenetically more closely related to each other than to any organism of another family. Only then can one say that Dermatophilus and Geodermatophilus are members of one family in the phylogenetic sense.

One of the well-established, reliable methods of elucidating relationships at the family level is the comparative analysis of $16 \mathrm{~S}$ ribosomal RNA. We have recently applied this method to the determination of the degree of natural relationship within the broad group of actinomycetes and coryneform organisms, including G. obscurus (Stackebrandt et al., 1983): G. obscurus was found to represent an individual line of descent within this group. We now present the results of $16 \mathrm{~S}$ rRNA analysis of $D$. congolensis, showing that this species is more closely related to Arthrobacter and related taxa than to $G$. obscurus. 


\section{METHODS}

Organism and cultivation. Dermatophilus congolensis DSM $43037(=$ IMRU V-1240 = A. Seino A-0081) was obtained from the Deutsche Sammlung von Mikroorganismen (DSM), Göttingen, F.R.G. The identity of this strain was confirmed by the DSM by morphology, analysis of the peptidoglycan and the presence of madurose (Lechevalier \& Lechevalier, 1981). The strain was cultivated in $600 \mathrm{ml}$ of a malt extract (Merck)/yeast extract (Oxoid)/glucose broth $(1: 0 \cdot 4: 0 \cdot 4 \%, \mathrm{w} / \mathrm{v})$ for $16 \mathrm{~h}$ at $37^{\circ} \mathrm{C}$.

$16 \mathrm{~S} r R N A$ analysis. Cells were broken by passing through a French pressure cell. The isolation of $16 \mathrm{~S}$ ribosomal RNA followed the methods described by Stackebrandt et al. (1981). Controlled digestion of RNA with RNAase $\mathrm{T}_{1}$, dephosphorylation of the $3^{\prime}$ end of oligonucleotides with alkaline phosphatase from calf intestine, enzymic in vitro labelling of the $5^{\prime}$ ends with $\left[\gamma_{-}^{32} \mathrm{P}\right] \mathrm{ATP}$ and polynucleotide kinase, and the determination of the nucleotide sequences, followed the description of Stackebrandt et al. $(1982 a)$. Binary matching coefficients $\left(S_{A B}\right.$ values) were calculated according to Fox et al. (1977). A dendrogram was generated from the $S_{A B}$ values by average linkage (between the merged groups) clustering.

Whole cell sugar, fatty acid and menaquinone analysis. Isolation and identification of whole cell sugars were done as described by Kroppenstedt (1977). Fatty acids were isolated according to Minnikin et al. (1975) and the composition determined using described methods (Kroppenstedt \& Kutzner, 1978). The isolation of menaquinones followed the method of Collins et al. (1977), modified by Kroppenstedt (1983); their identification was carried out by HPLC (Kroppenstedt, 1983).

\section{RESULTS AND DISCUSSION}

The oligonucleotide catalogue of the 16S rRNA of D. congolensis DSM 43037 is listed in Table 1, column 1. The presence of the oligonucleotides in catalogues of 18 strains of Arthrobacter and related taxa, 3 strains of Corynebacterium, 7 strains of Mycobacterium, Nocardia and Rhodococcus, 4 strains of Actinoplanes and related taxa, 6 strains of Streptomyces and related taxa, Streptosporangium roseum DSM 43021, Thermomonospora curvata DSM 43183 and $G$. obscurus DSM 43160 are shown in columns 2-9, respectively. Each column represents an individual line of descent within the phylogenetically defined group of the order Actinomycetales (Stackebrandt \& Woese, 1981; Stackebrandt et al., 1983). Of the 67 oligonucleotides constituting the 16S rRNA catalogue of $D$. congolensis, 28 are also present in the catalogues of almost all strains of the taxa listed in columns $2-9$, indicating that these oligonucleotides are highly conserved in the primary structure of the 16S rRNA of these organisms, and hence without significance in determining specific relationships. By far the highest number of additional identical oligonucleotides (17) is found between the catalogues of $D$. congolensis and at least $50 \%$ of the strains of that cluster defined by Arthrobacter and related organisms (Table 1, column 2). The number of additional common oligonucleotides between the catalogues of $D$. congolensis and the other phylogenetically defined groupings (columns 3-9) are much lower (8-12); $D$. congolensis and $G$. obscurus share only 9 common oligonucleotides in addition to the conserved ones.

The binary matching coefficients $\left(S_{A B}\right.$ values) for D. congolensis DSM 43037 and representatives of the phylogenetically defined groupings listed in Table 1, columns $2-9$ are given in Table 2. Figure 1 is a dendrogram, calculated from the $S_{A B}$ values. A more detailed picture of the phylogeny of the various groupings has already been published (Stackebrandt \& Woese, 1979, 1981; Stackebrandt et al., 1980, 1983).

Dermatophilus congolensis DSM 43037 shows similar high $S_{A B}$ values to representatives of Arthrobacter, Micrococcus, Cellulomonas, Promicromonospora, Brevibacterium and Microbacterium. The average linkage clustering, however, indicates that $D$. congolensis is slightly more closely related to species of a subcluster defined by the first four genera. No specific relationship can be detected between $D$. congolensis and $G$. obscurus: the degree of relationship found for the two species is only as high as that found between any two species of different main sublines within the order Actinomycetales.

The rather low degree of relatedness found between D. congolensis and G. obscurus is also seen in the lack of similarity of chemotaxonomic properties (Table 3).

Dermatophilus congolensis DSM 43037 possessed tetrahydromenaquinones with eight isoprene units [MK- $8\left(\mathrm{H}_{4}\right)$ ] as sole component, while $G$. obscurus contained tetrahydromenaquin- 


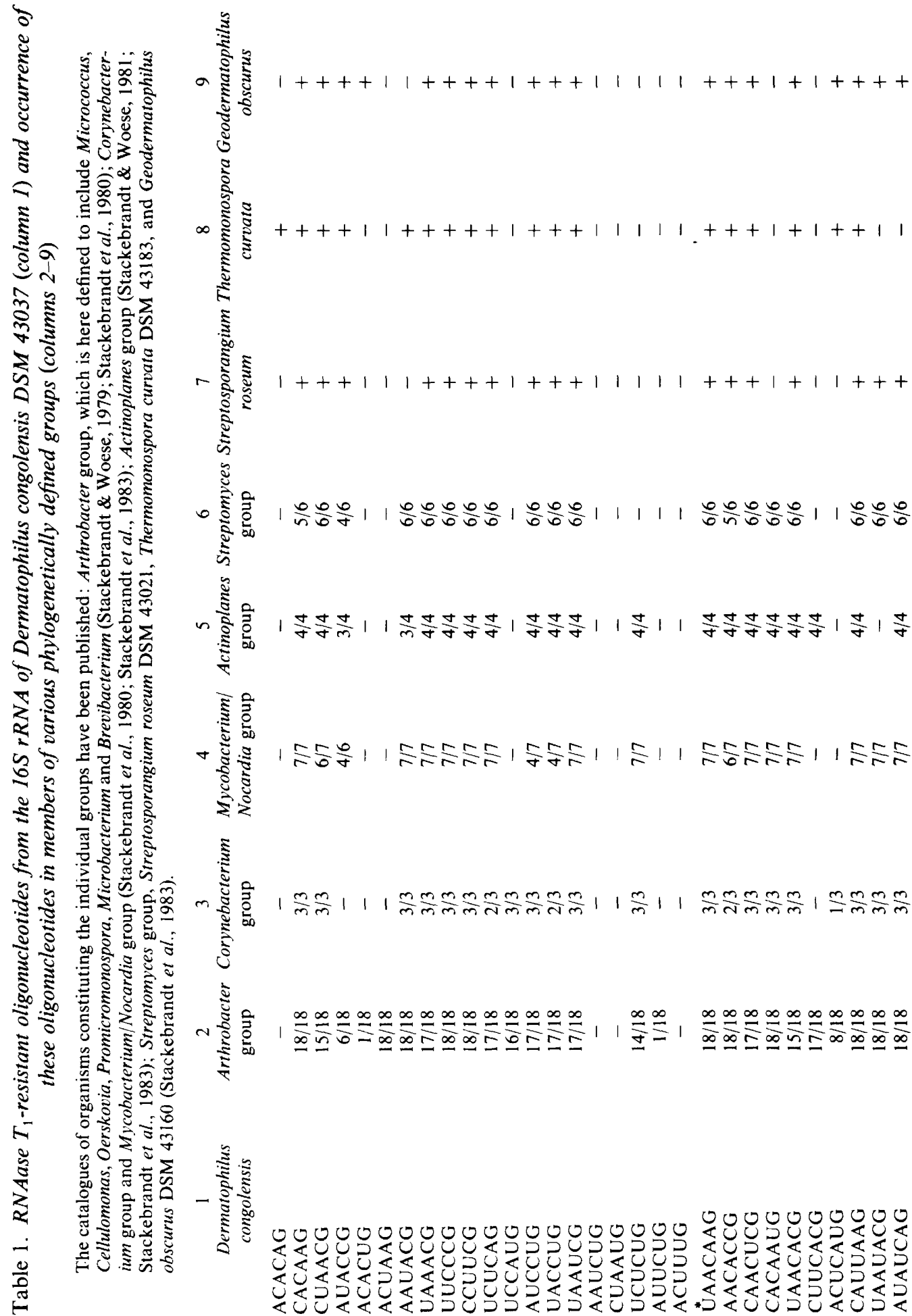




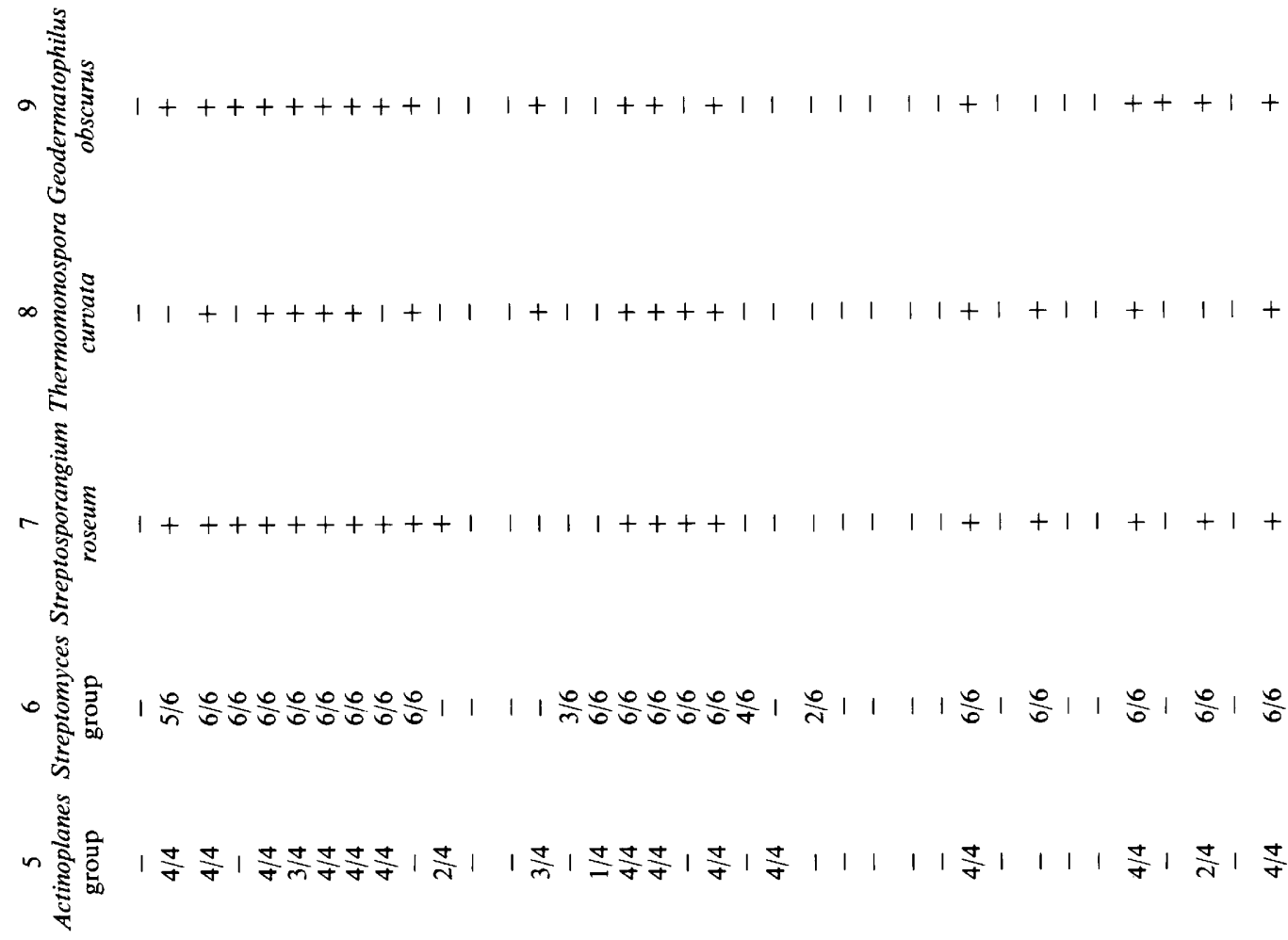

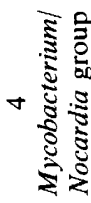

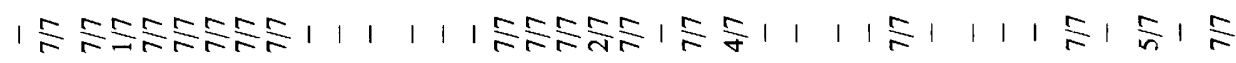

m

$\left|\frac{m}{m}\right| \frac{m}{n} \frac{m}{m} \frac{m}{-} \frac{m}{m}|\stackrel{m}{=}| 1\left|1 \frac{m}{m} \frac{m}{m} \frac{m}{m}\right| \frac{m}{m}|1| 1\left|\frac{m}{m}\right| 1\left|1 \frac{m}{m}\right| 1 \mid \frac{m}{m}$

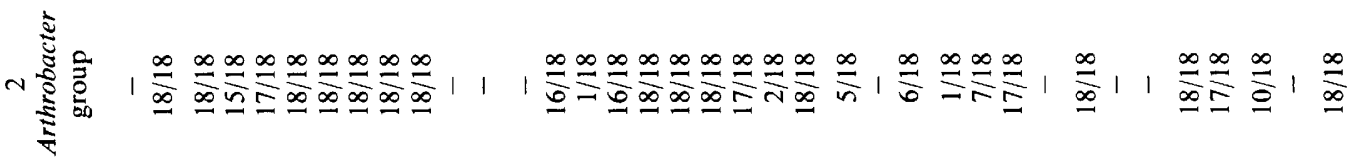

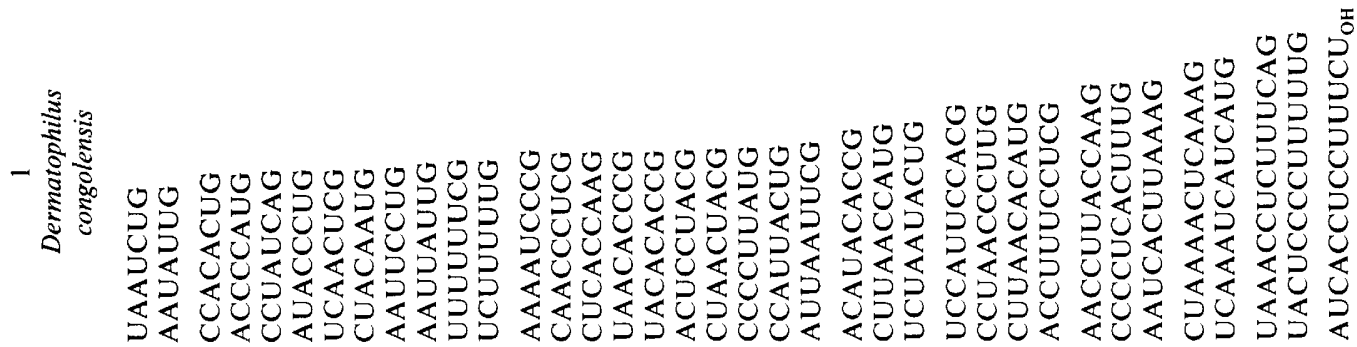


Table 2. Binary comparisons among the $16 S \mathrm{rRNA}$ catalogues from Dermatophilus congolensis DSM 43037 and Geodermatophilus obscurus and various representatives of actinomycetes and related taxa, expressed as $S_{A B}$ values

$\begin{array}{cc}\text { Dermatophilus } & \text { Geodermatophilus } \\ \text { congolensis } & \text { obscurus }\end{array}$

\author{
Arthrobacter group \\ Arthrobacter globiformis DSM 20124 \\ Arthrobacter oxydans DSM 20119 \\ Micrococcus luteus ATCC 23262 \\ Micrococcus roseus UWO 1057 \\ Micrococcus varians DSM 20033 \\ Cellulomonas group \\ Cellulomonas flavigena DSM 20109 \\ Cellulomonas cartae DSM 20106 \\ Oerskovia turbata NCIB 10587 \\ Microbacterium group \\ Microbacterium lacticum DSM 20172 \\ Corynebacterium betae DSM 20141 \\ Promicromonospora citrea DSM 43110 \\ Brevibacterium linens DSM 20158 \\ Corynebacterium group \\ Corynebacterium diphtheriae ATCC 11913 \\ Corynebacterium glutamicum ATCC 13059 \\ Arthrobacter variabilis DSM 20132 \\ Mycobacterium/Nocardia group \\ Mycobacterium phlei ATCC 11758 \\ 'Nocardia corallina' ATCC 4273 \\ Nocardia calcarea ATCC 19369 \\ Nocardia asteroides DSM 43245 \\ Corynebacterium fascians DSM 20131 \\ Actinoplanes group \\ Actinoplanes philippinensis DSM 43019 \\ Ampullariella regularis DSM 43151 \\ Dactylosporangium aurantiacum NRRL B8111 \\ Micromonospora chalcea NRLL B2344 \\ Streptomyces group \\ Streptomyces griseus strain 1947 \\ Kitasatoa kauaiensis DSM 43360 \\ Streptoverticillium baldaccii DSM 40845 \\ Elytrosporangium brasiliensis DSM 43159 \\ Streptosporangium roseum DSM 43021 \\ Thermomonospora curvata DSM 43183 \\ Geodermatophilus obscurus DSM 43160 \\ Dermatophilus congolensis DSM 43037
}

\begin{tabular}{|c|c|}
\hline 0.65 & 0.53 \\
\hline 0.63 & 0.50 \\
\hline 0.70 & 0.51 \\
\hline 0.67 & 0.47 \\
\hline 0.71 & 0.46 \\
\hline 0.66 & 0.49 \\
\hline 0.67 & 0.56 \\
\hline 0.65 & 0.52 \\
\hline 0.61 & 0.45 \\
\hline 0.69 & $0 \cdot 50$ \\
\hline 0.63 & 0.56 \\
\hline 0.58 & 0.43 \\
\hline 0.50 & 0.43 \\
\hline 0.47 & 0.38 \\
\hline 0.50 & 0.39 \\
\hline $0 \cdot 50$ & 0.43 \\
\hline 0.53 & 0.49 \\
\hline 0.55 & 0.46 \\
\hline 0.60 & 0.51 \\
\hline 0.57 & 0.47 \\
\hline 0.55 & 0.49 \\
\hline 0.51 & 0.50 \\
\hline 0.55 & 0.51 \\
\hline 0.52 & 0.50 \\
\hline 0.60 & 0.52 \\
\hline 0.62 & 0.55 \\
\hline 0.57 & 0.52 \\
\hline 0.59 & 0.52 \\
\hline 0.57 & 0.57 \\
\hline 0.51 & 0.46 \\
\hline 0.59 & 1.00 \\
\hline 1.00 & 0.59 \\
\hline
\end{tabular}

ones with nine isoprene units $\left[\mathrm{MK}-9\left(\mathrm{H}_{4}\right)\right]$ as sole component. The fatty acid composition of the two strains differed markedly. Thus $D$. congolensis had predominantly straight-chain fatty acids $(65 \%$ of total fatty acids) $(14: 0: 15: 0: 16: 0: 17: 0: 18: 0$ in ratios $14: 10: 33: 17: 7 \%)$ while $35 \%$ were composed of almost equal amounts of $\mathrm{C} 16, \mathrm{C} 17$ and $\mathrm{C} 18$ monounsaturated branched components. In contrast, G. obscurus had small amounts of straight-chain, anteiso branched and monounsaturated branched fatty acids $(20,19$ and $5 \%$, respectively) while $52 \%$ of total fatty acids were iso-branched components (i-14:i-15: i-16:i-17 in ratios $4: 26: 20: 2 \%$ ). Differences were also found in the whole cell sugar composition: $D$. congolensis contained madurose (Lechevalier and Lechevalier, 1981) in addition to smaller amounts of glucose and ribose, while in agreement with Lechevalier \& Lechevalier (1981) no sugar of diagnostic value was found in $G$. obscurus, which contained only small amounts of galactose, glucose and ribose. 


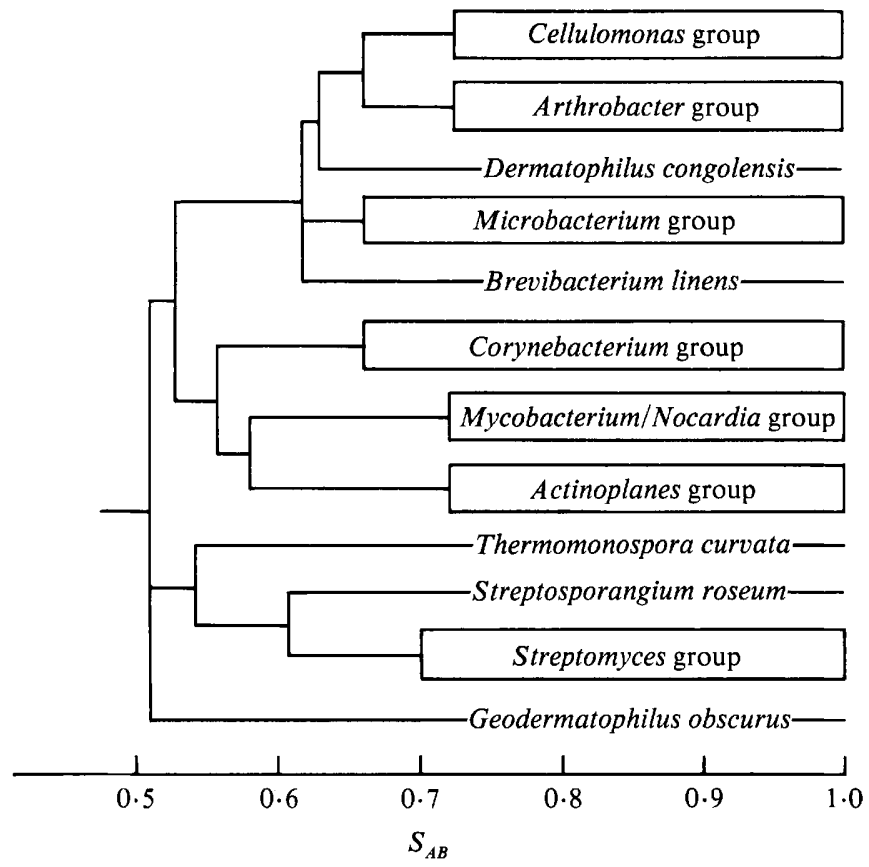

Fig. 1. Dendrogram derived by average linkage clustering using a Dice-type similarity coefficient, $S_{A B}$ (Fox et al., 1977).

Table 3. Chemical characters of Dermatophilus and phylogenetically related genera and of Geodermatophilus

Literature references are indicated by superscript letters: $a$, Samsonoff et al. (1977); $b$, Keddie \& Jones (1981); c, Kloos et al. (1974); d, Stackebrandt et al. (1982b); e, Goodfellow \& Minnikin (1981); $f$, Schleifer \& Kandler (1972); $g$, Collins \& Jones (1981); $h$, Kroppenstedt (1977); $i$, Collins et al: (1982).

Abbreviations. Peptidoglycan: Ala, alanine; m-Dpm, meso-diaminopimelic acid; Glu, glutamic acid; Lys, lysine; Orn, ornithine; $\mathrm{Ib}^{*}$, interpeptide bridge with variable amino acids. Isoprenoid quinones: MK, menaquinone (the numbers indicate the number of isoprenoid units, and $\mathrm{H}_{2}$, etc., indicates the degree of hydrogenation). Fatty acids: $\mathrm{S}$, straight chain; $\mathrm{U}$, monounsaturated; I, iso; $\mathrm{A}$, anteiso (main components italicized). Sugars: Gal, galactose; Glc, glucose; Mad, madurose; Man, mannose; Rham, rhamnose; Rib, ribose.

\begin{tabular}{|c|c|c|c|c|c|c|}
\hline \multirow[b]{2}{*}{ Taxon } & \multirow{2}{*}{$\begin{array}{c}\text { DNA G }+C \\
\text { content } \\
(\text { mol } \%)\end{array}$} & \multicolumn{2}{|c|}{ Peptidoglycan } & \multirow{2}{*}{$\begin{array}{l}\text { Major } \\
\text { isoprenoid } \\
\text { quinone }\end{array}$} & \multirow{2}{*}{$\begin{array}{l}\text { Fatty } \\
\text { acids }\end{array}$} & \multirow{2}{*}{$\begin{array}{c}\text { Cell } \\
\text { sugars }\end{array}$} \\
\hline & & Typef & Group $f$ & & & \\
\hline Dermatophilus & $57 \cdot 4-58 \cdot 7^{a}$ & $\mathrm{~m}-\mathrm{Dpm}$ & & $\mathrm{MK}-8\left(\mathrm{H}_{4}\right)$ & $S, \mathrm{U}^{h}$ & Glc, Mad, Rib \\
\hline $\begin{array}{l}\text { Arthrobacter } \\
\text { sensu stricto } \dagger\end{array}$ & $59-66^{b}$ & L-Lys-Ib* & & MK-9( $\left.\mathrm{H}_{2}\right)^{g}$ & $\mathrm{~S}, \mathrm{I}, A^{e}$ & $\mathrm{Gal}^{e}$ \\
\hline Micrococcus & $64-73^{c}$ & L-Lys-Ib* & & $\mathrm{MK}-7 / 8\left(\mathrm{H}_{2}\right)^{g}$ & ND & ND \\
\hline $\begin{array}{l}\text { Cellulomonas/ } \\
\text { Oerskovia }\end{array}$ & $70 \cdot 5-76 \cdot 6^{d}$ & $\begin{array}{l}\text { L-Orn-Ib*/ } \\
\text { L-Lys-Ib* }\end{array}$ & A & MK $-9\left(\mathrm{H}_{4}\right)^{9}$ & $\mathrm{~S}, \mathrm{I}, A^{e}$ & $\begin{array}{l}\text { Man, Rham, } \\
\text { Ribe Gale }^{e}\end{array}$ \\
\hline Promicromonospora & $73-74^{e}$ & L-Lys-L-Ala, & & $\mathrm{MK}-9\left(\mathrm{H}_{4}\right)^{g}$ & $\mathrm{~S}, \mathrm{I}, A^{e}$ & Gal, Glce \\
\hline Brevibacterium & $60-64^{b}$ & m-Dpm & & $\mathrm{MK}-8\left(\mathrm{H}_{2}\right)^{g}$ & $\mathrm{~S}, \mathrm{I}, A^{e}$ & Glc, Gal, Ribe \\
\hline Microbacterium & $69-70^{b}$ & L-Lys-D-Glu & B & $\mathrm{MK}-10 / 11 / 12$ & $\mathrm{~S}, \mathrm{I}, A^{i}$ & Gal, Rhame \\
\hline Geodermatophilus & $72 \cdot 9-74 \cdot 6^{a}$ & $\mathrm{~m}-\mathrm{Dpm}$ & A & MK- $9\left(\mathrm{H}_{4}\right)$ & $\mathrm{S}, I, \mathrm{~A}^{h}$ & Glc, Gal, Rib \\
\hline
\end{tabular}

ND, Not determined.

$\uparrow$ As defined by Keddie \& Jones (1981). 
The work reported here supports earlier findings concerning the genetic and phenotypical heterogeneity of the family Dermatophilaceae (Samsonoff et al., 1977; Goodfellow \& Pirouz, 1982; Roberts, 1981) although the extent to which the two species are related could not be detected previously. Our results exclude the possibility that Dermatophilus and Geodermatophilus are members of one phylogenetically defined family. The data on G. obscurus point towards its classification in a family of its own, because of the isolated position of this species within the phylogenetic tree of the actinomycetes and related taxa. In contrast, $D$. congolensis cannot be defined as a genus representing a family of its own and is rather a representative of a genus which is phylogenetically equivalent to the genera of the coryneform and actinomycete group of organisms, i.e. Arthrobacter, Micrococcus, Cellulomonas, Promicromonospora, Brevibacterium and Microbacterium. The distinct position of Dermatophilus within this group is also shown by the differences in chemotaxonomic markers (Table 3).

It is surprising to find an organism with such complex morphology to belong in the same phylogenetic grouping as mainly rod-shaped or even spherical bacteria. However, other morphologically fairly complex forms, such as branched or even mycelium-producing organisms, have recently been shown to be closely related to the morphologically simpler forms (Stackebrandt \& Woese, 1979; Stackebrandt et al., 1982 b; Döpfer et al., 1982). Our result on the relationship between $D$. congolensis and G. obscurus is another example of the unsuitability of morphological features in the systematics of bacteria, if a taxonomic rank above the species level is to mirror a true natural relationship.

This research was supported by a grant from the Deutsche Forschungsgemeinschaft.

\section{REFERENCES}

Collins, M. D. \& Jones, D. (1981). Distribution of isoprenoid quinone structural types and their taxonomic implications. Microbiological Reviews 45, 316-354.

Collins, M. D., Pirouz, T., Goodfellow, M. \& Minnikin, D. E. (1977). Distribution of menaquinones in actinomycetes and corynebacteria. Journal of General Microbiology 100, 221-230.

Collins, M. D., Jones, D. \& Kroppenstedt, R. M. (1982). Reclassification of 'Corynebacterium laevaniformans' (Dias and Bhat) in a redefined genus Microbacterium (Orla-Jensen), as Microbacterium imperiale comb.nov. and Microbacterium laevaniformans nom. rev.; comb.nov. Systematic and Applied Microbiology 4, 65-78.

DöPfer, H., Stackebrandt, E. \& Fiedler, F. (1982). Nucleic acid hybridization studies on Microbacterium, Curtobacterium, Agromyces and related taxa. Journal of General Microbiology 128, 16971708.

Fox, G. E., Pechman, K. R. \& Woese, C. R. (1977). Comparative cataloguing of $16 \mathrm{~S}$ ribosomal ribonucleic acid: molecular approach to procaryotic systematics. International Journal of Systematic Bacteriology 27, 44-57.

Goodfellow, M. \& MinNikin, D. E. (1981). Introduction to the coryneform bacteria. In The Prokaryotes, pp. 1811-1826. Edited by M. P. Starr, H. Stolp, H. G. Trüper, A. Balows \& H. G. Schlegel. Berlin, Heidelberg, New York: Springer.

Goodfellow, M. \& Pirouz, T. (1982). Numerical classification of sporoactinomycetes containing meso-diaminopimelic acid in the cell wall. Journal of General Microbiology 128, 503-527.

GotTlieb, D. (1974). Actinomycetales. In Bergey's Manual of Determinative Bacteriology, pp. 657-659.
Edited by R. E. Buchanan \& N. E. Gibbons. Baltimore: Williams \& Wilkins.

KedDie, R. M. \& Jones, D. (1981). Saprophytic, aerobic coryneform bacteria. In The Prokaryotes, pp. 1838-1878. Edited by M. P. Starr, H. Stolp, H. G. Trüper, A. Balows \& H. G. Schlegel. Berlin, Heidelberg, New York: Springer.

Kloos, W. E., Tornabene, T. G. \& Schleifer, K. H (1974). Isolation and characterization of micrococci from human skin, including two new species: Micrococcus lylae and Micrococcus kristinae. International Journal of Systematic Bacteriology 24, 79101.

KROPPENSTEDT, R. (1977). Untersuchungen zur Chemotaxonomie der Ordnung Actinomycetales, Buchanan. Ph.D. thesis, Technische Hochschule, Darmstadt, F.R.G.

KROPPENSTEDT, R. (1983). Separation of bacterial menaquinones by HPLC using reverse phase (RP 18) and a silver loaded ion exchanger as stationary phase. Journal of Liquid Chromatography 5, 2359-2367.

KROPPENSTEDT, R. \& KutZNER, H. J. (1978). Biochemical taxonomy of some problem actinomycetes. Zentralblatt für Bakteriologie, Abteilung I, Suppl. 6, 125-133.

Lechevalier, H. A. \& Lechevalier, M. P. (1981). Introduction to the order Actinomycetales. In The Prokaryotes, pp. 1915-1922. Edited by M. P. Starr, H. Stolp, H. G. Trüper, A. Balows \& H. G. Schlegel. Berlin, Heidelberg, New York: Springer.

Lechevalier, H. A., Lechevalier, M. P. \& Gerber, N. N. (1971). Chemical composition as a criterion in the classification of actinomycetes. Advances in Applied Microbiology 14, 47-72.

LuedeMAN, G. M. (1968). Geodermatophilus, a new 
genus of the Dermatophilaceae (Actinomycetales). Journal of Bacteriology 96, 1848-1858.

Minnikin, D. E., Alshamaony, L. \& Goodfellow, M. (1975). Differentiation of Mycobacterium, Nocardia and related taxa by thin layer chromatographic analysis of whole organism methanolysates. Journal of General Microbiology 88, 200-204.

ROBERTS, D. S. (1981). The family Dermatophilaceae. In The Prokaryotes, pp. 2011-2015. Edited by M. P. Starr, H. Stolp, H. G. Trüper, A. Balows \& H. G. Schlegel. Berlin, Heidelberg, New York: Springer.

Samsonoff, W. A., Detlefsen, M. A., Fonseca, A. F. \& EDWARDS, M. R. (1977). Deoxyribonucleic acid base composition of Dermatophilus congolensis and Geodermatophilus obscurus. International Journal of Systematic Bacteriology 27, 22-25.

Schleifer, K. H. \& Kandler, O. (1972). Peptidoglycan types of bacterial cell walls and their taxonomic implications. Bacteriological Reviews 36, 407-477.

StackebrandT, E. \& Woese, C. R. (1979). A phylogenetic dissection of the family Micrococcaceae. Current Microbiology 2, 317-322.

StaCkebrandT, E. \& Woese, C. R. (1981). Towards a phylogeny of the actinomycetes and related organisms. Current Microbiology 5, 131-136.
Stackebrandt, E., Lewis, B. J. \& Woese, C. R. (1980). The phylogenetic structure of the coryneform group of bacteria. Zentralblatt für Bakteriologie, Abteilung I, Originale C 2, 137-149.

Stackebrandt, E., Ludwig, W., Schleifer, K. H. \& Gross, H. J. (1981). Rapid cataloguing of ribonuclease $T_{1}$ resistant oligonucleotides from ribosomal RNAs for phylogenetic studies. Journal of Molecular Evolution 17, 227-236.

Stackebrandt, E., Seewaldt, E., Ludwig, W., SChleifer, K. H. \& Huser, B. A. (1982a). The phylogenetic position of Methanothrix soehngenii. Elucidated by a modified technique of sequencing oligonucleotides from 16S rRNA. Zentralblatt für Bakteriologie, Abteilung I, Originale C 3, 90-100.

Stackebrandt, E., Seiler, H. \& Schleifer, K. H. $(1982 b)$. Union of the genera Cellulomonas Bergey et al. and Oerskovia Prauser et al. in a redefined genus Cellulomonas. Zentralblatt für Bakteriologie, Abteilung I, Originale C 3, 401-409.

Stackebrandt, E., Ludwig, W., SeewaldT, E. \& SCHLEIFER, K. H. (1983). Phylogeny of sporeforming members of the order Actinomycetales. International Journal of Systematic Bacteriology (in the Press). 